\title{
Effects of galantamine in a 2-year, randomized, placebo-controlled study in Alzheimer's disease [Corrigendum]
}

Hager K, Baseman AS, Nye JS, Brashear HR, Han J, Sano M, Davis B, Richards HM. Neuropsychiatr Dis Trea. 2014; 10:391-401.
"- Gal at stable dose (at least $18 \mathrm{mg} /$ day) as achieved on day $84^{\text {c" }}$ should be "- Gal at stable dose (at least $16 \mathrm{mg} /$ day) as achieved on day $84^{\circ}$ ". The correct figure is shown below.

On page 393, Figure 1, "Maintenance period (month 6 to 24)" should be "Maintenance period (month 4 to 24)";

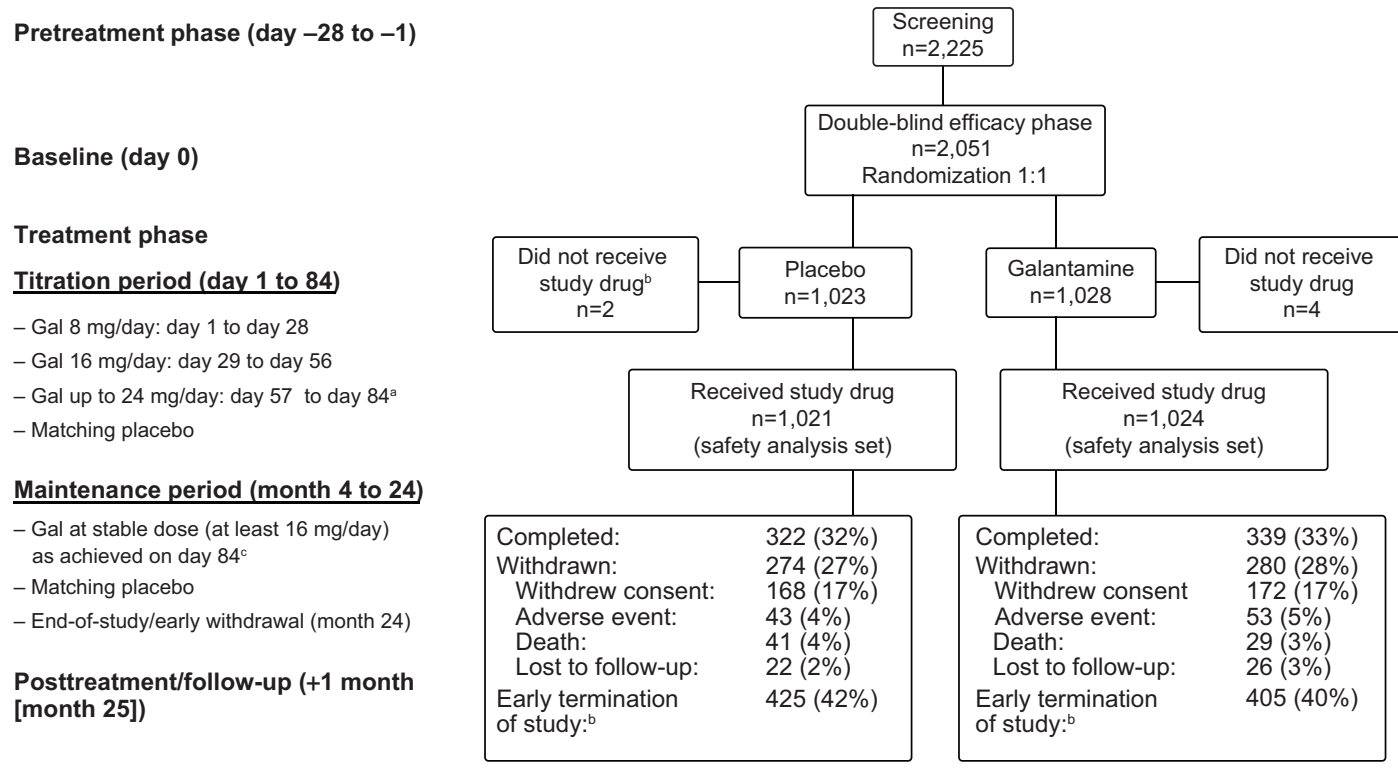

Notes: 'Uptitration (from $16 \mathrm{mg} /$ day to $24 \mathrm{mg} /$ day) or downtitration (from $24 \mathrm{mg} /$ day to $16 \mathrm{mg} /$ day) of dose was allowed, based on tolerability and the investigator's judgment. Patients unable to tolerate a minimum of $16 \mathrm{mg} /$ day dose were to discontinue treatment and were followed until the end of the maintenance and posttreatment period. The total number of patients included in the safety analysis set was n=2,045; bearly study termination, per Data Safety Monitoring Board recommendation, when the prespecified number of deaths was ascertained and a significant imbalance favoring galantamine was observed; ca one-time dose titration to 16 or $24 \mathrm{mg} /$ day was allowed, based on the investigator's judgment and patient tolerability.

Abbreviation: Gal, galantamine.

\section{Publish your work in this journal}

Neuropsychiatric Disease and Treatment is an international, peerreviewed journal of clinical therapeutics and pharmacology focusing on concise rapid reporting of clinical or pre-clinical studies on a range of neuropsychiatric and neurological disorders. This journal is indexed on PubMed Central, the 'PsycINFO' database and CAS, and is the official journal of The International Neuropsychiatric Association (INA). The manuscript management system is completely online and includes a very quick and fair peer-review system, which is all easy to use. Visit http://www.dovepress.com/testimonials.php to read real quotes from published authors. 